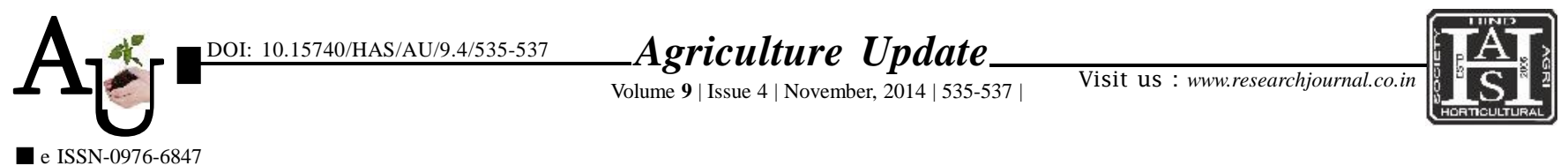

Research Article

\title{
Resource use management in coconut based homesteads among the small farm families of central Kerala
}

\section{S. HELEN AND SMITHA BABY}

Article Chronicle : Received :

25.06.2014;

Revised :

28.09.2014;

Accepted :

07.10.2014

KEY WoRds :

Resource use

management,

Coconut based

homesteads,

Small farm

families
SUMMARY : Present study was conducted in the six agro-ecosystems of Central zone of Kerala with the holistic approach in the coconut based homesteads of small farm families. To determine the performance of the selected homesteads, resource use management strategies practiced by the participating small farm families from each agro-ecosystem were assessed. It indicated that majority of the small farm families were not efficiently using the resources under integrated nutrient management (INM) and integrated pest and disease management practices (IPM). Among the components of resource use management, it was found that the contribution of water management was the maximum to the net income followed by capital management and integrated nutrient management. Therefore, the technologies related to these three areas have to be given more thrust in transfer of technology in increasing the net income of the coconut based homesteads.

How to cite this article : Helen, S. and Baby, Smitha (2014). Resource use management in coconut based homesteads among the small farm families of central Kerala. Agric. Update, 9(4): 535-537.
Author for correspondence :

\section{S. HELEN}

Department of

Agricultural Extension,

Communication Centre,

Kerala Agricultural

University, THRISSUR

(KERALA) INDIA

Email: helen.s@kau.in

See end of the article for

authors' affiliations 